TELAGA BAHASA

Volume 5

No. 1 Juni 2017

Halaman 63-82

\title{
TINDAK TUTUR ASERTIF DALAM PIDATO PELANTIKAN DONALD TRUMP DI GEDUNG CAPITOL WASHINGTON DC
}

\author{
(Assertive Speech Act in Donald Trump Inaguration Speech \\ in Capitol Building Washington Dc)
}

Irawan Syahdi

Balai Bahasa Aceh

Jalan Panglima Nyak Makam no.21 Banda Aceh, 23125

Pos-el: irawan_syahdi@yahoo.com

\begin{abstract}
Abstrak
Tindak ilokusi adalah tindak tutur yang tidak hanya berfungsi untuk menginformasikan sesuatu namun juga mempengaruhi lawan tutur untuk melakukan sesuatu. Kajian ini membahas tentang tindak tutur ilokusi asertif dalam pidato pelantikan Donald trump di Gedung Capitol Washington DC tepat pada hari jumat 20 Januari 2017. Penelitian ini bersifat deskriptif kualitatif dengan menggunakan teori tindak tutur yang dikemukakan oleh Searle dan ahli lainnya.Teknik yang digunakan dalam kajian tindak tutur ini adalah teknik catat dan pustaka. Dari hasil kajian yang dilakukan ada beberapa fungsi tindak tutur asertif yang ditemukan pada pidato tersebut yaitu: menyatakan, menegaskan, mengajak, memberitahukan, mengeluh, membanggakan, dan berjanji.
\end{abstract}

Kata kunci: pidato, tindak tutur, ilokusi, asertif

\begin{abstract}
Illocutionary acts serve not only to inform but also affect the hearers to do something. This study discusses the assertive illocutionary acts in Donald trump's inauguration speech at Capitol Building in Washington DC, on Friday January 20, 2017. This is a descriptive qualitative study using speech acts theory proposed by Searle and others. The technique used in this study of speech acts are noting and references. From the results of studies conducted there are some functions of assertive speech acts found in the speech that is: state, inform, assert, suggest, complain, boast, and promise.
\end{abstract}

Keywords: speech, speech acts, illocutionary, assertive 


\section{PENDAHULUAN}

Manusia, dalam hal ini sebagai penutur sebuah bahasa selalu bertindak tutur melalui ucapan-ucapan mereka dalam mengungkapkan suatu maksud, perasaan, pendapat, dan pikiran, ketika melakukan komunikasi. Melalui ujaran tersebut, seorang penutur dapat mempengaruhi mitra tuturnya untuk melakukan apa yang ia maksud. Suatu makna atau maksud tuturan tersebut dapat terjadi ialah karena adanya penutur, situasi tutur, dan struktur dalam bahasa itu sendiri. Ketika seseorang berbicara, mereka tidak hanya menghasilkan ujaran yang mengandung kalimat gramatikal (kalimat tanya, kalimat perintah, kalimat pernyataan) saja, tetapi juga melakukan tindakan melalui ucapan mereka. Bahkan pada tataran kata pun mampu mengungkapkan suatu maksud di dalamnya. Ujaran-ujaran yang demikian itu disebut dengan tindak tutur (speech act).

Pidato adalah salah satu cara berkomunikasi, yaitu komunikasi satu arah. Pidato biasanya digunakan oleh seorang pemimpin untuk memimpin dan berorasi di depan banyak anak buahnya atau khalayak ramai. Pidato umumnya melakukan satu atau beberapa hal seperti memengaruhi orang lain agar mau mengikuti kemauan kita dengan suka rela, memberi suatu pemahaman atau informasi pada orang lain. Selanjutnya, pada setiap komunikasi yang terjadi akan terjadi interaksi di antara penutur dan mitra tutur yang dapat berupa informasi seperti penuangan gagasan, maksud, perasaan, pikiran secara langsung. Proses komunikasi itu disebut sebagai peristiwa tutur. Peristiwa tutur merupakan berlangsungnya interaksi linguistik dalam satu bentuk ujaran atau lebih yang melibatkan dua pihak, yaitu penutur dan lawan tutur, dengan satu pokok tuturan, di dalam waktu, tempat, dan situasi tertentu (Chaer, 2010: 47).

Menurut Wijana (1996:46) tindak tutur merupakan unsur pembentuk aktivitas berbahasa, sedangkan Ibrahim (1993:294) menjelaskan bahwa tindak tutur adalah ujaran-ujaran yang merupakan tindakan (action). Lain halnya dengan Tarigan (1986:33) yang mengungkapkan bahwa telaah mengenai bagaimana cara kita melakukan sesuatu adalah telaah mengenai tindak ujar atau tindak tutur (speech act). Dari pendapat tersebut dapat dikatakan bahwa tindak tutur adalah tindak verbal yang digunakan untuk menyatakan sesuatu sekaligus melakukan sesuatu. Oleh karena itu, dapat diambil kesimpulan bahwa tindak tutur adalah sebuah proses aktivitas berbahasa yang berupa kalimat dalam bentuk ujaran (percakapan) antara penutur dan mitratutur untuk menghasilkan suatu tindakan. 
Tindak tutur dibedakan menjadi dua aspek, yaitu maksud penutur dan bagaimana penutur mencoba mempengaruhi mitra tuturnya untuk melakukan sesuatu. Situasi dimana ucapan tersebut diucapkan akan mempengaruhi penafsiran yang berbeda oleh mitra tutur atau pendengarnya. Selanjutnya Searle (1979:21), membagi tindak ilokusi berdasarkan fungsinya menjadi lima kategori, yaitu assertives (asertif), directives (direktif), commissives (komisif), expressives (ekspresif) dan declarations (deklarasi). Asertif adalah tindak tutur yang mengikat penuturnya kepada kebenaran atas apa yang dikatakannya. Direktif merupakan tindak tutur yang dimaksudkan agar lawan tutur melakukan tindakan yang disebutkan dalam ujaran. Komisif merupakan tindak tutur yang mengikat penuturnya untuk melakukan apa yang disebutkan dalam ujaran. Ekspresif adalah tindak tutur yang dimaksudkan untuk mengekspresikan atau mengungkapkan sikap psikologis penutur. Yang terakhir deklarasi ialah tindak tutur yang dilakukan penutur dengan maksud untuk menciptakan hal (termasuk di dalamnya status dan keadaan) yang baru. Penelitian ini hanya difokuskan pada salah satu tindak tutur, yaitu tindak tutur asertif menjawab (answering).

Searle dalam Wijana (2009: 21-24) membagi tiga jenis tindak tutur, yaitu tindak tutur lokusi, tindak tutur ilokusi maupun tindak tutur perlokusi. Tindak tutur lokusi adalah tindak tutur untuk menyatakan sesuatu. Tindak tutur ilokusi adalah tindak tutur yang tidak hanya berfungsi untuk menginformasikan sesuatu namun juga untuk melakukan sesuatu. Tindak perlokusi adalah tindak tutur untuk mempengaruhi lawan tutur.

Searle (dalam Rahardi, 2005: 35-36) menyatakan bahwa dalam praktiknya terdapat tiga macam tindak tutur antara lain:

(1) tindak lokusioner,

(2) tindak ilokusioner, dan

(3) tindak perlokusi.

Tindak lokusioner adalah tindak bertutur dengan kata, frasa, dan kalimat sesuai dengan makna yang dikandung oleh kata, frasa, d’an kalimat itu. Kalimat ini dapat disebut sebagai the act of saying something. Dalam lokusioner tidak dipermasalahkan maksud dan fungsi tuturan yang disampaikan maksud dan fungsi tuturan yang disampaikan oleh si penutur.

Selanjutnya, Searle (dalam Rahardi, 2005:36) ${ }^{7}$ menggolongkan tindak tutur ilokusi itu ke dalam lima macam bentuk tuturan yang masing-masing memiliki fungsi komunikatif. Kelima macam bentuk tuturan yang menunjukkan fungsi itu dapat dirangkum sebagai berikut: 


\section{Asertif (Assertives),}

Asertif adalah bentuk tuturan yang mengikat penutur pada kebenaran proposisi yang diungkapkan, misalnya menyatakan (stating), menyarankan (suggesting), menbual (boasting), mengeluh (complaining), dan mengklaim (claiming), menuntut, mengakui, menunjukkan, melaporkan, memberikan kesaksian, menyebutkan, dan berspekulasi.

Direktif(Directives),

Direktif adalah bentuk tuturan yang dimaksudkan penuturannya untuk membuat pengaruh agar si mitra tutur melakukan tindakan, misalnya, memesan (ordering), memerintah (commanding), memohon (requesting), menasehati (advising), dan merekomendasi (recommending), meminta, mengajak, memaksa, mendesak, menyuruh, menagih, mendesak, menantang, dan memberi aba-aba.

\section{Ekspresif (Expressives)}

Ekspresif adalah bentuk tuturan yang berfungsi untuk menyatakan atau menunjukkan sikap psikologis penutur terhadap suatu keadaan, misalnya berterima kasih (thanking), memberi selamat (congratulating), meminta maaf (pardoning), menyalahkan (blambing), memuji (praising), berbelasungkawa (condoling), mengeluh, menyanjung, dan mengkritik.

Komisif(Commissives),
Komisif adalah bentuk tuturan yang berfungsi untuk menyatakan janji atau penawaran, misalnya berjanji (promising), bersumpah (vowing), dan menawarkan sesuatu (offering), mengancam, menyatakan kesanggupan, berkaul.

\section{Deklarasi (Declarations),}

Deklarasi adalah bentuk tuturan yang menghubungkan isi tuturan dengan kenyataan, misalnya berpasrah (resigning), memecat (dismissing), menbaptis (chistening), memberi nama (naming), mengangkat (appointing), mengucilkan (excommicating), dan menghukum (sentencing). mengesankan, memutuskan, membatalkan, melarang, mengabulkan, mengizinkan, menggolongkan, mengangkat, mengampuni, dan memaafkan.

\section{Fungsi Tindak Tutur Asertif (Assertives)}

Menurut Searle (dalam Tarigan, 1986: 46) ${ }^{4}$, pada ilokusi ini penutur terikat pada kebenaran proposisi yang diungkapkan; misalnya menyatakan, memberitahukan, menyarankan, membanggakan, menyombongkan, mengeluh, menuntut, dan melaporkan. Adapun penjelasan dari fungsi asertif ini sebagai berikut. 
a) Menyatakan

Fungsi tuturan menyatakan adalah suatu tuturan atau ungkapan untuk memberikan suatu informasi atau menginformasikan sesuatu kepada seseorang.

b) Memberitahukan

Fungsi tuturan memberitahukan adalah tuturan yang menginformasikan sesuatu kepada lawan tuturnya.

c) Menyarankan

Fungsi tuturan menyarankan adalah tuturan atau ungkapan yang memberikan saran atau pendapat kepada seseorang untuk melakukan apa yang disarankan.

d) Membanggakan

Fungsi tuturan membanggakan adalah tuturan atau ungkapan yang digunakan untuk menyatakan rasa bangga. Ilokusi yang seperti ini tidak masuk dalam kategoti netral dari segi kesopanan dan dianggap tidak sopan yang secara semantis, asertif bersifat proposisional

e) Menyombongkan

Fungsi tuturan menyombongkan adalah tuturan atau ungkapan yang digunakan untuk menyatakan rasa sombong.
Tuturan tersebut masuk ke dalam kategori tuturan yang tidak sopan.

f) Mengeluh

Fungsi tuturan mengeluh adalah menyatakan susah karena penderitaan, kesakitan, kekecewaan, dsb.

g) Menuntut

Fungsi tuturan menuntut adalah tuturan yang menyatakan suatu tuntutan kepada seseorang dan mempunyai maksud untuk melakukan sesuatu.

h) Melaporkan

Fungsi tuturan melaporkan adalah menyatakan informasi kepada seseorang dengan maksud untuk melakukan sesuatu.

Sementara menurut Leech $(1993: 327)^{8}$, tindak tutur asertif dapat dibuktikan dengan kehadiran verba tertentu yang mengikat penutur dan kebenaran yang proposisi yang sedang diungkapkannya. Kemudian Fraser ( dalam Nadar, 2009: 16) ${ }^{9}$, berdasarkan apa yang diutarakan oleh Leech, mengemukakan beberapa kata kerja asertif seperti: menuduh, mengakui, menambahkan, mengakui, mengajurkan, menegaskan, setuju, mengatakan, mengumumkan, menilai, berpendapat, persetujuan, menegaskan, 
membuktikan, menegaskan, klaim, komentar, keadaan di dunia, dalam hal ini apa yang mengakui, menyimpulkan, Setuju, mengaku, dinyatakan mengandung kebenaran. mengkonfirmasi, dugaan, menyatakan, Representatif di sini dibagi menjadi dua menyimpulkan, mencela, menyangkal, tidak yakni pernyataan dan penjelasan. Pernyataan setuju, sengketa, menekankan, adalah tuturan yang berisi informasi. mengakui/jamin, tahan, menginformasikan, Penjelasan adalah ujaran yang bersifat menjaga, menyebutkan, catatan, menginformasikan, tuturan yang sifatnya memberitahu, mengamati, menunjukkan, memberi penjelasan. posyulate, memprediksi, memberitakan, mengaku, protes, menegaskan kembali, mengakui, menolak, komentar,

\section{METODE PENELITIAN}

mengingatkan, ulangi , membalas, laporan, Jenis Penelitian

merespon, membantah, katakanlah, Penelitian ini menggunakan jenis menyatakan, menyerahkan, menyarankan, bersumpah, mengatakan, verifikasi, dan memperingatkan).

Kemudian menurut Leech (dalam Sudaryat, 2009: 140$)^{10}$, kalimat asertif adalah kalimat yang berfungsi untuk mengekspresikan kebenaran informasi. Kebenaran kalimat memiliki tiga macam perwujudan, yakni kalimat analitis, yang kebenaran isinya berada di dalam untaian kata-katanya; kalimat kontradiktif, yang kebenaran isi kalimatnya bertolak belakang dengan isi untaian kata-katanya; dan kalimat sintesis, yang kebenaran isi kalimatnya bergantung kepada fakta yang ada di luar bahasa.

Sedang menurut Searle (dalam Dardjowidjojo, 2003: 95) ${ }^{11}$, asertif atau representatif adalah pernyataan tentang suatu

\section{Data dan Sumber Data Penelitian}

Data analisis dalam penelitian ini adalah berupa tindak tutur asertif yang dikelompokan berdasarkan bentuk tuturan asertif yaitu bentuk berita, tanya, dan perintah serta fungsi tuturan asertifnya yaitu fungsi menyatakan, memberitahukan, menyarankan, membanggakan, mengeluh, menuntut, dan melaporkan. Sedang sumber data penelitian ini adalah pidato pelantikan presiden Amerika ke-45 Donald Trump di Gedung Capitol Washington DC pada hari 
Jumat 20 Januari 2017 yang terdiri dari 55 baris kalimat, dan telah diterjemahkan ke dalam bahasa Indonesia, dikutip dari https://papuapost.wordpress.com/2017/01/22/ teks-lengkap-pidato-inaugurasi-donaldtrump/ pukul 11.36 pada 30/03/2017.

\section{Teknik Pengumpulan Data}

Teknik pengumpulan data menggunakan teknik pustaka dan teknik catat. Tenik catat adalah teknik yang digunakan untuk mencatat data-data ke dalam kartu pencatat data (Sudaryanto, 1993: 134). Penulis mencatat tindak tutur beserta maksim-maksimnya ke dalam kartu pencatat data. Kemudian penulis menggunakan teknik pustaka, teknik pustaka adalah mempergunakan sumber-sumber tertulis untuk memperoleh data. Sumber-sumber tertulis itu meliputi majalah, surat kabar, dan karya sastra ( Subroto, 1992: 42 ). Penulis menggunakan buku acuan pragmatik dari berbagai sumber yang ada dan juga buku mengenai teknik analisis bahasa. Dalam penelitian ini, peneliti menggunakan instrumen berupa alat bantu yang meliputi alat tulis dan kartu pencatat data. Hasil dari pembacaan serta pengamatan penulis terhadap teks pidato yang berkaitan dengan tindak tutur asertif, kemudian dicatat dalam kartu data. Adapun bentuk atau format kartu data yang dipergunakan adalah sebagai berikut:

\begin{tabular}{|c|c|}
\hline No & $: 1$ \\
\hline Baris & $: 2$ \\
\hline Data & $\begin{array}{l}\text { : Kita, warga Amerika, kini bersama-sama berusaha membangun } \\
\text { negara kita dan mengembalikan janji kepada seluruh rakyat. }\end{array}$ \\
\hline Kontek & $\begin{array}{l}\text { ג: Donald Trump di hadapan para pendukungnya menyampaikan } \\
\text { pidato pelantikan sebagai Presiden ke-45 Amerika Serikat pada } \\
\text { Jumat, } 20 \text { Januari di Gedung Capitol di Washington DC. }\end{array}$ \\
\hline Fungsi & : Menyatakan \\
\hline
\end{tabular}

\section{PEMBAHASAN}

Pembahasan tindak tutur atau speech acts pada pidato pelantikan Donald Trump sebagai presiden Amerika ke-45 ini terdiri dari 55 (lima puluh lima) baris kalimat. Data tuturan asertif yang telah diperoleh 
berdasarkan hasil pengamatan, interpretasi serta pemahaman penulis yang kemudian dimasukkan kedalam kartu data dan dianalisis fungsi dari setiap data tuturan asertif tersebut. Perlu diketahui bahwa tuturan asertif yang terdapat dalam teks pidato tersebut semuaya terkait dengan satu konteks tempat, waktu dan situasi saja yaitu dimana pidato tersebut dilakukan, yaitu di Gedung Capitol Washington DC, pada hari jumat tanggal 20 Januari dihadapan para pendukungnya, partai Republik, pada saat pelantikan beliau sebagai presiden Amerika ke-45.

Pembahasan kajian tindak tutur ini disajikan dengan menggunakan tabel untuk lebih memudahkan pemahaman dan lebih jelasnya paparan data serta hasil yang diperoleh.

\begin{tabular}{|c|c|c|c||}
\hline No & Baris & \multicolumn{1}{|c|}{ Asertif } & Fungsi \\
\hline \hline 1 & 2 & $\begin{array}{l}\text { Kita, warga Amerika, kini bersama-sama } \\
\text { berusaha membangun negara kita dan } \\
\text { mengembalikan janji kepada seluruh rakyat. }\end{array}$ & Menyatakan \\
\hline 2 & 3 & $\begin{array}{l}\text { Bersama, kita akan menentukan ke mana } \\
\text { Amerika dan dunia akan menuju di tahun-tahun } \\
\text { mendatang. Kita akan menghadapi tantangan. } \\
\text { Kita akan menghadapi kesulitan. Tapi kita akan } \\
\text { membereskan semuanya. Ase 3 mengajak }\end{array}$ & Mengajak \\
\hline 3 & 4 & $\begin{array}{l}\text { Setiap empat tahun kita berkumpul di sini untuk } \\
\text { menyelesaikan proses pergantian kekuasaan } \\
\text { secara tertib dan damai. Ase 4 menyatakan }\end{array}$ & Menyatan \\
\hline 5 & 8 & $\begin{array}{l}\text { Bagaimana pun juga, perayaan hari ini, punya } \\
\text { makna khusus karena hari ini kita tidak sekadar } \\
\text { memindahkan kekuasaan dari satu pemerintahan } \\
\text { ke pemerintahan lain, dari satu partai ke partai } \\
\text { lain, tapi kita memindahkan kekuasaan dari } \\
\text { Washington D.C kembali kepada kalian, rakyat } \\
\text { Amerika. Ase 8 memberitahukan }\end{array}$ & Memberitahukan \\
\hline $\begin{array}{l}\text { Sudah sejak lama, segelintir orang di ibu kota } \\
\text { negara kita mengambil keuntungan dari } \\
\text { pemerintah, sementara rakyat menanggung } \\
\text { bebannya. Washington bersinar, tapi rakyat tidak } \\
\text { mendapat bagian apa-apa. Politisi makmur tapi } \\
\text { lapangan kerja berkurang dan pabrik-pabrik }\end{array}$ & \\
\hline & 9 & \\
\hline
\end{tabular}




\begin{tabular}{|c|c|c|c|}
\hline & & ditutup. Ase 9 komplain & \\
\hline 6 & 10 & \begin{tabular}{|l} 
Kemapanan melindungi dirinya sendiri, tapi \\
tidak warga negara kita. Kejayaan mereka \\
bukanlah kejayaan kalian. Kesuksesan mereka \\
bukan milik kalian. Dan sementara mereka \\
merayakan kemenangan di ibu kota negara kita, \\
tak ada perayaan bagi perjuangan para keluarga \\
di seantero negeri kita. Ase 10 Komplain
\end{tabular} & Mengeluh \\
\hline 7 & 11 & $\begin{array}{l}\text { Itu semua akan berubah mulai sekarang, saat ini, } \\
\text { karena saat ini adalah milik kalian. Milik semua } \\
\text { orang yang berkumpul di sini dan orang-orang } \\
\text { yang menyaksikan ini di seluruh Amerika.ase } \\
11 \text { memberitahukan }\end{array}$ & Memberitahukan \\
\hline 8 & 12 & $\begin{array}{l}\text { Hari ini milik kalian. Ini perayaan kalian. Dan } \\
\text { Amerika Serikat adalah negara kalian.ase } 12 \\
\text { memberitahukan }\end{array}$ & Memberitahukan \\
\hline 9 & 13 & \begin{tabular}{|l} 
Yang penting bukanlah partai mana yang \\
menguasai pemerintahan, tapi soal apakah \\
rakyat menguasai pemerintah. Ase 13 \\
menyatakan
\end{tabular} & Reaffirm/menegaskan \\
\hline 10 & 14 & $\begin{array}{l}20 \text { Januari } 2017 \text { akan dikenang sebagai hari } \\
\text { ketika rakyat kembali menjadi penguasa negara } \\
\text { ini. Ase } 14 \text { Menyatakan }\end{array}$ & Menyatakan \\
\hline 11 & 15 & $\begin{array}{l}\text { Kaum laki-laki dan perempuan yang selama ini } \\
\text { terlupakan, tidak akan terabaikan lagi. Semua } \\
\text { orang mendengar kalian sekarang. Berpuluh- } \\
\text { puluh juta kalian datang berbondong-bondong } \\
\text { untuk menjadi bagian dari gerakan sejarah, } \\
\text { sesuatu yang belum pernah terjadi sebelumnya. } \\
\text { Ase } 15 \text { memberitahukan }\end{array}$ & Memberitahukan \\
\hline 12 & 16 & $\begin{array}{l}\text { Inti dari semua ini adalah keyakinan bahwa } \\
\text { negara melayani rakyatnya. Rakyat Amerika } \\
\text { ingin sekolah yang bagus buat anak-anak } \\
\text { mereka, ingin lingkungan yang aman bagi } \\
\text { keluarga mereka dan pekerjaan yang layak. Ase } \\
16\end{array}$ & Menuntut \\
\hline & & & \\
\hline
\end{tabular}




\begin{tabular}{|c|c|c|c|}
\hline 13 & 17 & $\begin{array}{l}\text { Ini semua tuntutan wajar dan masuk akal bagi } \\
\text { orang-orang dan masyarakat yang baik ase. } 17 \\
\text { Menyatakan }\end{array}$ & Menegaskan \\
\hline 14 & 18 & $\begin{array}{l}\text { Tapi bagi rakyat kebanyakan, yang terjadi } \\
\text { sebaliknya. Ase } 18 \text { Komplain }\end{array}$ & Mengeluh \\
\hline 15 & 19 & $\begin{array}{l}\text { Ibu-ibu dan anak terperangkap dalam } \\
\text { kemiskinan di kota-kota, pabrik-pabrik } \\
\text { terbengkalai layaknya batu nisan di seantero } \\
\text { negara kita. Ase } 19 \text { Komplain }\end{array}$ & Mengeluh \\
\hline 16 & 20 & $\begin{array}{l}\text { Sistem pendidikan dipenuhi banyak uang tapi } \\
\text { hanya membuat para pemuda kita tidak tahu } \\
\text { apa-apa. Ase } 20 \text { Komplain }\end{array}$ & Mengeluh \\
\hline 17 & 21 & $\begin{array}{l}\text { Kejahatan, gang, dan narkoba, merampas begitu } \\
\text { banyak nyawa dan merampok banyak potensi } \\
\text { tersembunyi negara kita. Pembantaian besar- } \\
\text { besaran ini cukup berhenti sampai di sini.ase } 21 \\
\text { Memberitahukan }\end{array}$ & Melaporkan \\
\hline 18 & 22 & $\begin{array}{l}\text { Kita adalah satu, dan penderitaan mereka adalah } \\
\text { penderitaan kita. Ase } 22 \text { Menyatakan }\end{array}$ & Menyatakan \\
\hline 19 & 23 & $\begin{array}{l}\text { Impian mereka adalah impian kita, dan } \\
\text { kesuksesan mereka akan menjadi kesuksesan } \\
\text { kita. Kita merasakan hal sama, kita punya rumah } \\
\text { bersama dan masa depan gemilang.ase } \\
\text { Menyatakan }\end{array}$ & Menyatakan \\
\hline 20 & 24 & $\begin{array}{l}\text { Sumpah jabatan saya hari ini adalah sumpah } \\
\text { setia kepada seluruh rakyat Amerika.ase 24 } \\
\text { Memberitahukan }\end{array}$ & Memberitahukan \\
\hline 21 & 25 & $\begin{array}{l}\text { Selama berpuluh tahun kita memperkaya } \\
\text { industri luar negeri dengan ongkos dari industri } \\
\text { Amerika, menyumbang kekuatan militer negara } \\
\text { lain sementara militer kita sendiri dibiarkan } \\
\text { merosot. Ase } 25 \text { Komplain }\end{array}$ & Mengeluh/menyombongkan \\
\hline 22 & 26 & $\left|\begin{array}{lllr}\text { Kita mempertahankan perbatasan } & \text { negara lain } \\
\text { sementara tidak perbatasan } & \text { kita. } & \text { Kita } \\
\text { menghabiskan triliunan dolar di luar } & \text { negeri } \\
\text { sementara infrastruktur kita melemah } & \text { dan } \\
\text { ambruk berantakan. Ase 26 Komplain } & \end{array}\right|$ & Mengeluh/menyombongkan \\
\hline
\end{tabular}




\begin{tabular}{|c|c|c|c|}
\hline 23 & 27 & $\begin{array}{l}\text { Kita membuat negara lain kaya sementara } \\
\text { kekayaan, kekuatan, dan kepercayaan diri kita } \\
\text { memudar. Ase } 27 \text { Komplain }\end{array}$ & Mengeluh/menyombongkan \\
\hline 24 & 28 & $\begin{array}{l}\text { Satu persatu pabrik tutup dan pergi } \\
\text { meninggalkan negara kita tanpa memikirkan } \\
\text { nasib jutaan pekerja Amerika. Ase } 28 \text { Komplain }\end{array}$ & Mengeluh \\
\hline 25 & 29 & $\begin{array}{l}\text { Kekayaan kelas menengah kita dirampok dari } \\
\text { rumah-rumah mereka dan disebarkan ke } \\
\text { seantero dunia. Tapi itu semua masa lalu, } \\
\text { sekarang kita menatap masa depan. Ase } 29 \\
\text { Komplain/Menyatakan }\end{array}$ & Mengeluh/menyombongkan \\
\hline 26 & 30 & $\begin{array}{l}\text { Kita berkumpul di sini hari ini untuk } \\
\text { menyampaikan pesan yang akan didengar di } \\
\text { setiap kota, di setiap ibu kota negara, dan di } \\
\text { setiap pusat kekuasaan. Mulai hari ini ke depan, } \\
\text { sebuah pemerintahan dengan visi baru akan } \\
\text { memimpin negara kita. Ase } 30 \text { Memberitahukan }\end{array}$ & Menyatakan \\
\hline 27 & 31 & \begin{tabular}{|l} 
Sejak hari ini, semuanya hanya untuk \\
kepentingan Amerika lebih dulu, Amerika lebih \\
dulu. Semua keputusan perdagangan, pajak, \\
imigrasi, kebijakan luar negeri akan dibuat untuk \\
kepentingan para pekerja Amerika dan keluarga \\
Amerika. Kita harus melindungi perbatasan dari \\
perampasan negara lain terhadap produk-produk \\
kita, mencuri perusahaan kita dan \\
menghancurkan lapangan kerja kita. Ase 31 \\
Berjanji/Mengajak
\end{tabular} & Berjanji/mengajak/menyarankan \\
\hline 28 & 32 & $\begin{array}{l}\text { Proteksi akan membuat kita makmur dan kuat. } \\
\text { Saya akan berjuang demi kalian, dengan seluruh } \\
\text { napas yang ada dan saya tidak akan membuat } \\
\text { kalian kecewa. Ase } 32 \text { Berjanji }\end{array}$ & Berjanji \\
\hline 29 & 33 & $\begin{array}{l}\text { Amerika akan kembali berjaya, lebih hebat dari } \\
\text { sebelumnya. Kita akan kembalikan lapangan } \\
\text { kerja. Kita akan kembalikan perbatasan. Kita } \\
\text { akan kembalikan kekayaan kita dan impian kita. } \\
33 \text { Berjanji }\end{array}$ & Berjanji \\
\hline 30 & 34 & Kita akan bangun jalan baru, jalan bebas & Berjanji \\
\hline
\end{tabular}




\begin{tabular}{|c|c|c|c|}
\hline & & $\begin{array}{l}\text { hambatan, jembatan, bandara, dan terowongan, } \\
\text { serta jalur kereta di seantero negeri yang indah } \\
\text { ini. Ase } 34 \text { Berjanji }\end{array}$ & \\
\hline 31 & 35 & $\begin{array}{l}\text { Kita akan membuat rakyat miskin kembali } \\
\text { bekerja, membangun negara kita dengan tenaga } \\
\text { kerja Amerika. Ase } 35 \text { Berjanji/Mengajak }\end{array}$ & Berjanji \\
\hline 32 & 36 & $\begin{array}{l}\text { Kita akan mematuhi dua aturan sederhana: beli } \\
\text { produk Amerika dan pekerjakan warga Amerika. } \\
\text { Ase } 36 \text { Berjanji/Mengajak }\end{array}$ & Berjanji \\
\hline 33 & 37 & $\begin{array}{l}\text { Kita akan menjalin persahabatan dengan negara } \\
\text { lain di dunia, tapi dengan keyakinan bahwa } \\
\text { adalah setiap negara untuk menempatkan } \\
\text { kepentingan mereka masing-masing lebih dulu. } \\
\text { Ase } 37 \text { Berjanji/Mengajak }\end{array}$ & Berjanji \\
\hline 34 & 38 & $\begin{array}{l}\text { Kita tidak akan memaksakan gaya hidup kita } \\
\text { kepada orang lain, tapi lebih memberinya contoh } \\
\text { untuk ditiru. Ase } 38 \text { Berjanji/Mengajak }\end{array}$ & Menyombongkan \\
\hline 35 & 39 & $\begin{array}{l}\text { Kita akan menjadi contoh bagi orang lain. Ase } \\
\text { 39/Membanggakan }\end{array}$ & Membanggakan \\
\hline 36 & 40 & $\mid \begin{array}{l}\text { Kita akan memperkuat hubungan lama dan } \\
\text { membuat lagi yang baru serta bersama-sama } \\
\text { warga dunia melawan terorisme Islam radikal. } \\
\text { Kita akan memberantas habis mereka dari muka } \\
\text { bumi. Ase } 40 \text { Berjanji/ }\end{array}$ & Berjanji \\
\hline 37 & 41 & $\mid \begin{array}{l}\text { Pondasi dasar politik kita total akan berupa } \\
\text { kepatuhan kepada Amerika Serikat, dan dengan } \\
\text { kesetiaan kepada negara, kita akan } \\
\text { membangkitkan lagi rasa saling setia itu. Ase } 41 \\
\text { Berjanji }\end{array}$ & Berjanji \\
\hline 38 & 42 & $\begin{array}{l}\text { Ketika kalian membuka diri bagi patriotisme, } \\
\text { tidak ada ruang untuk berburuk sangka. Ase } 42\end{array}$ & Memberitahukan \\
\hline 39 & 43 & $\mid \begin{array}{l}\text { Alkitab mengatakan betapa baik dan nyaman } \\
\text { rasanya ketika Tuhan hidup bersama di hati } \\
\text { setiap orang. Kita harus menyampaikan } \\
\text { pendapat kita secara bebas, berdebat secara jujur } \\
\text { terus terang, tapi tetap menjaga solidaritas. }\end{array}$ & Menyatakan \\
\hline
\end{tabular}




\begin{tabular}{|c|c|c|c|}
\hline & & $\begin{array}{l}\text { Ketika Amerika bersatu, Amerika tidak akan } \\
\text { terbendung. Jangan ada lagi rasa takut. Kita } \\
\text { dilindungi dan selalu dilindungi. Kita akan } \\
\text { dilindungi oleh tentara laki-laki dan perempuan } \\
\text { hebat di militer kita dan para penegak hukum } \\
\text { kita. Dan yang terpenting kita akan dilindungi } \\
\text { Tuhan. Ase } 43\end{array}$ & \\
\hline 40 & 44 & $\begin{array}{l}\text { Akhirnya, kita harus berpikir hal besar dan } \\
\text { mengimpikan hal lebih besar. Di Amerika, kita } \\
\text { paham, sebuah negara akan bertahan hanya jika } \\
\text { terus berusaha. Kita tidak akan lagi menerima } \\
\text { politisi yang hanya bisa bicara tanpa berbuat, } \\
\text { mereka yang terus-terusan mengeluh tanpa } \\
\text { berbuat apa-apa. Ase } 44\end{array}$ & Menyarankan \\
\hline 41 & 45 & $\begin{array}{l}\text { Omong kosong belaka kini sudah tamat. Kini } \\
\text { tiba saatnya bertindak. Ase } 45\end{array}$ & Menegaskan \\
\hline 42 & 47 & $\begin{array}{l}\text { Kita berada di era milenium baru, kita siap } \\
\text { menjelajah misteri antariksa, membebaskan } \\
\text { dunia dari segala penyakit, dan memanfaatkan } \\
\text { segala sumber daya alam, industri dan teknologi } \\
\text { masa depan. Ase } 47\end{array}$ & menyombongkan \\
\hline 43 & 48 & $\begin{array}{l}\text { Harkat martabat bangsa akan menjadi pegangan } \\
\text { kita dan menambah kehormatan serta } \\
\text { menghapus perbedaan. Ini saatnya mengingat } \\
\text { kembali kebijaksaan dari para tentara, tidak soal } \\
\text { kita berkulit hitam, coklat, atau putih, darah kita } \\
\text { semua sama merahnya. Ase } 48\end{array}$ & Mengingatkan \\
\hline 44 & 49 & $\begin{array}{l}\text { Kita semua menikmati kebebasan dan kita } \\
\text { menghormat bendera Amerika yang sama. Ase } \\
49\end{array}$ & Menyatakan \\
\hline 45 & 50 & $\begin{array}{l}\text { Setiap bayi yang lahir di tengah padatnya Kota } \\
\text { Detroit atau di hamparan dingin Nebraska, } \\
\text { mereka menatap langit yang sama, mereka } \\
\text { punya impian yang sama dan bernapas berkat } \\
\text { daya hidup pemberian Tuhan yang sama. Ase } \\
50\end{array}$ & Menyatakan \\
\hline 46 & 51 & $\mid \begin{array}{l}\text { Kepada seluruh rakyat Amerika, baik di kota } \\
\text { besar, kecil, di gunung-gunung, di samudera, } \\
\text { dengarkan kata-kata ini: kalian tidak akan lagi }\end{array}$ & Berjanji \\
\hline
\end{tabular}




\begin{tabular}{|c|c|c|c|}
\hline & & $\begin{array}{l}\text { diabaikan. Suara kalian, harapan kalian, impian } \\
\text { kalian dan menentukan masa depan Amerika. } \\
\text { Keberanian, kebijaksanaan, dan cinta kalian } \\
\text { akan senantiasa menuntun kita meraih cita-cita. } \\
\text { ase } 51\end{array}$ & \\
\hline 47 & 52 & $\begin{array}{l}\text { Bersama kita akan membuat Amerika kuat lagi, } \\
\text { kaya lagi, bangga lagi, dan aman lagi. Dan ya, } \\
\text { bersama kita akan membuat Amerika hebat lagi. } \\
\text { Ase } 52\end{array}$ & Mengajak \\
\hline 48 & 54 & Tuhan memberkati. Ase 54 & Menyatakan \\
\hline 49 & 55 & Semoga Tuhan memberkati Amerika. ase 55 & Menyatakan \\
\hline \multicolumn{2}{|c|}{ Total } & \multicolumn{2}{|l|}{ 49 Data Asertif } \\
\hline
\end{tabular}

Dalam teks asli pidato Donald Trump ini banyak ditemukan kalimat Present Future Tense dengan menggunakan kata 'will', dan diterjamhakan menjadi kata 'akan' dalam bahasa Indonesia, yang mempunyai beberapa makna dalam penggunaanya dalam kalimat seperti:

1. mengekspresikan permintaan, ajakan, dan menawarkan sesuatu,

2. mengekspresikan janji,

3. mengekspresikan prediksi yang menggunakan kata kerja dan frase seperti: percaya,

berharap, perkirakan, pikir/rasa, saya takut/kuatir dan saya yakin,

4. mengungkapkan niat yang kuat atau pernyataan tentang masa depan, dan

5. mengekspresikan probabilitas atau harapan tentang sesuatu di masa sekarang.
Kata 'will/akan' juga bisa bersinonim dengan kata-kata seperti cenderung, memiliki kecenderungan untuk, terikat untuk, melakukan, dan harus.

Dari hasil yang terdapat dalam tabel dapat dijelaskan bahwa Donald Trump banyak memberikan pernyataan-pernyataan yang berkaitan dengan kondisi Amerika pada pemerintahan presiden yang terlebih dahulu mengenai sistem pemerintahan, kebijakan yang diambil serta kondisi perekonoian sekaligus masyarakat yang dianggapnya tidak memihak kepada kepentingan masyarakat Amerika yang kemudian diungkapnya juga dengan mengeluh akan beberapa hal seperti:

"Sudah sejak lama, segelintir orang di ibu kota negara kita mengambil keuntungan dari pemerintah, sementara rakyat menanggung bebannya. Washington bersinar, tapi rakyat 
tidak mendapat bagian apa-apa. Politisi makmur tapi lapangan kerja berkurang dan pabrik-pabrik ditutup".

"Kemapanan melindungi dirinya sendiri, tapi tidak warga negara kita. Kejayaan mereka bukanlah kejayaan kalian. Kesuksesan mereka bukan milik kalian. Dan sementara mereka merayakan kemenangan di ibu kota negara kita, tak ada perayaan bagi perjuangan para keluarga di seantero negeri kita”.

"Tapi bagi rakyat kebanyakan, yang terjadi sebaliknya".

"Ibu-ibu dan anak terperangkap dalam kemiskinan di kota-kota, pabrik-pabrik terbengkalai layaknya batu nisan di seantero negara kita".

"Sistem pendidikan dipenuhi banyak uang tapi hanya membuat para pemuda kita tidak tahu apa-apa".

"Satu persatu pabrik tutup dan pergi meninggalkan negara kita tanpa memikirkan nasib jutaan pekerja Amerika".

Kemudiaan ada tuturan Donald Trump yang sangat kontradiksi dimana di satu sisi dia mengeluh akan sesuatu hal tapi di sisi lain dia membanggakan sesuatu penyebab keluhannya tersebut seperti yang terlihat dalam tuturan berikut:
1. Mengeluh akan kemerosotan industri serta kekuatan militer Amerika dikarenakan Amerika telah banyak menyumbang ongkos industrinya demi kekayaan industri negara kain dan menyumbang kekuatan kepada negara lain.

"Selama berpuluh tahun kita memperkaya industri luar negeri dengan ongkos dari industri Amerika, menyumbang kekuatan militer negara lain sementara militer kita sendiri dibiarkan merosot."

2. Mengeluh masalah keamanan perbatasan lemahnya infrastruktur dikarenakan Amerika sibuk mempertahankan perbatasan negara lain dan menghabiskan triliunan dollar di luar negri.

"Kita mempertahankan perbatasan negara lain sementara tidak perbatasan kita. Kita menghabiskan triliunan dolar di luar negeri sementara infrastruktur kita melemah dan ambruk berantakan”.

3. Mengeluh memudarnya kepercayaan dikarenakan Amerikalah yang telah membuat negara lain kaya.

"Kita membuat negara lain kaya sementara kekayaan, kekuatan, dan kepercayaan diri kita memudar". 
4. Mengeluh karena kekayaan "Itu semua akan berubah mulai sekarang, masyarakat Ameria dirampok demi negara saat ini, karena saat ini adalah milik kalian. lain.

Milik semua orang yang berkumpul di sini

"Kekayaan kelas menengah kita dirampok dari rumah-rumah mereka dan disebarkan ke seantero dunia. Tapi itu semua masa lalu, sekarang kita menatap masa depan”.

Ada tuturan Donald Trump bahkan yang menyatakan kesombongan yaitu:

Kemudian dia memberitahukan tentang hal-hal seperti:

"Kita berada di era milenium baru, kita siap menjelajah misteri antariksa, membebaskan "Bagaimana pun juga, perayaan hari ini, punya makna khusus karena hari ini kita tidak sekadar memindahkan kekuasaan dari satu pemerintahan ke pemerintahan lain, dari satu partai ke partai lain, tapi kita memindahkan kekuasaan dari Washington D.C kembali kepada kalian, rakyat dunia dari segala penyakit, dan memanfaatkan segala sumber daya alam, industri dan teknologi masa depan".

"Kita tidak akan memaksakan gaya hidup kita kepada orang lain, tapi lebih memberinya contoh untuk ditiru". Amerika".

Tentunya sebagai presiden terpilih "Kaum laki-laki dan perempuan yang selama Donald Trump pastinya memberikan janjiini terlupakan, tidak akan terabaikan lagi. janji yang dapat dilihat dari tutuan berikut Semua orang mendengar kalian sekarang. ini:

Berpuluh-puluh juta kalian datang "Amerika akan kembali berjaya, lebih hebat berbondong-bondong untuk menjadi bagian dari sebelumnya. Kita akan kembalikan dari gerakan sejarah, sesuatu yang belum lapangan kerja. Kita akan kembalikan pernah terjadi sebelumnya". perbatasan. Kita akan kembalikan kekayaan kita dan impian kita”.

"Ketika kalian membuka diri bagi patriotisme, tidak ada ruang untuk berburuk sangka".

"Kita akan bangun jalan baru, jalan bebas hambatan, jembatan, bandara, dan terowongan, serta jalur kereta di seantero negeri yang indah ini”. 
"Kita akan membuat rakyat miskin kembali bekerja, membangun negara kita dengan cita". tenaga kerja Amerika".

"Kita akan mematuhi dua aturan sederhana: beli produk Amerika dan pekerjakan warga Amerika".

"Kita akan menjalin persahabatan dengan negara lain di dunia, tapi dengan keyakinan bahwa adalah setiap negara untuk menempatkan kepentingan mereka masingmasing lebih dulu".

"Kita akan memperkuat hubungan lama dan membuat lagi yang baru serta bersama-sama warga dunia melawan terorisme Islam radikal. Kita akan memberantas habis mereka dari muka bumi”".

"Pondasi dasar politik kita total akan berupa kepatuhan kepada Amerika Serikat, dan dengan kesetiaan kepada negara, kita akan membangkitkan lagi rasa saling setia itu'.

"Kepada seluruh rakyat Amerika, baik di kota besar, kecil, di gunung-gunung, di samudera, dengarkan kata-kata ini: kalian tidak akan lagi diabaikan. Suara kalian, harapan kalian, impian kalian dan tidaklah berada dipundaknya sendiri tapi juga menentukan masa depan Amerika. pada masyarakat AS atas terwujudnya janji-
Keberanian, kebijaksanaan, dan cinta kalian akan senantiasa menuntun kita meraih cita-

Namun ada hal yang perlu diperhatikan bahwa dalam teks pidatonya Donald Trump banyak sekali menggunakan kata 'we' diterjemahkan menjadi 'kita' dalam bahasa Indonesia yang maknanya menurut $\mathrm{KBBI} \mathbf{k i t a} / \mathrm{ki} \cdot \mathrm{ta} /$ pron 1 pronomina persona pertama jamak, yang berbicara bersama dengan orang lain termasuk yang diajak bicara; (http://kbbi.web.id/kita). Kata ganti 'kita' memiliki sifat eksklusif, yakni orang yang diajak berbicara terlibat dalam aktivitas atau keadaan yang sedang dituturkan. Dalam hal ini kata kita mengacu kepada pembicara dan lawan bicara. (https:// notulabahasa.wordpress.com/2013/12/16/ka mi-dan-kita-memang-berbeda/.

Jadi, kalau ditelisik secara seksama dalam semua tuturan asertif yang diucapkannya Donald Trump tidaklah mengucapkan pernyataan, pemberitahuan, membanggakan dan terutama berjanji atas namanya sendiri tapi melainkan atas nama seluruh masyarakat Amerika dengan banyaknya dia menggunakan kata ganti 'we'/'kita'.

Jadi, dalam hal ini tangguang jawab paca masyarakat AS atas terwujudnya janji- 
janji yang terucapkan. Dalam hal ini Donald pada dasarnya adalah seorang yang tidak berani bertangung jawab atas misi-misnya mejabat sebagai presiden Amerika, dan bila ada suatu kesalahan selama dia menjabat maka tanggung awab moral sekali lagi ada pada selauruh rakyat Amerika sendiri.

Satu satunya tuturan aserif yang menandung janji Donald Trump sebagai presiden terpilih atas nama dirinya sendiri adalah:

"Proteksi akan membuat kita makmur dan kuat. Saya akan berjuang demi kalian, dengan seluruh napas yang ada dan saya tidak akan membuat kalian kecewa".

\section{SIMPULAN}

Dari hasil kajian tindak tutur asertif yang terdapat dalam teks pidato pelantikan Donald Trump maka dapat disimpulkan bahwa

1. Dari 55 (lima puluh lima) baris kalimat yang terdapat dalam teks pidato pelantikan tersebut ditemukan ada 49 tindak tutur asertif.

2. Terdapat 6 (enam) tindak tutur ekspresif yang terdiri dari 2 fungsi ekspresif yaitu

a. Berterimakasih

b. Memuji

3. Fungsi-fungsi yang ditemukan dari 49 tuturan asertif tersebut adalah menyatakan memberitahukan, menegaskan, menuntut, mengeluh, membanggakan, menyombongkan, berjanji, mengajak, dan menyarankan.

4. Donald Trump banyak menggunakan kalimat Present Future dalam menyampaikan isi pidato pelantikannya

5. Donald Trump juga banyak menggunakan kata ganti "we" yang diterjemahkan menjadi "kita" kedalam bahasa Indonesia hingga apapun isi pidato yang dia sampaikan tidaklah mengacu hanya kepada dirinya sendiri tapi kepada seluruh rakyat Amerika.

\section{SARAN}

Banyak kajian ataupun penelitian bisa dilakkan oleh seorang peneliti dan begitupun banyak juga objek ataupun bahan yang bisa diteliti seperti wacana baik dalam bentuk lisan seperti percakapan, wawancara atau pidato, dan tertulis seperti berupa buku, majalah novel, cerpen, cerita rakyat dan lain lain. Dalam hal ini kajian atau penelitian tindak tutur merupakan salah satu diantaranya yang pastinya bermanfaat tidak hanya bagi akademisi tapi juga masyarakat pada umumnya.

Kajian tindak tutur apabila dikaji dan dikupas jauh lebih dalam maka akan memungkinkan bagi peneliti untuk mengetahui 1. Tipe ataupun karakter dari seseorang terutama pemimpin suatu negara, 
tentang bagaimana dia akan memimpin kelak dan 2. Dapat memprediksi kebijakan yang akan dilakukan atau dilaksanakan oleh seseorang atau pemerintahan tertentu dan yang tentunya akan sangat bermanfaat sekali bagi kemaslahatan masyarakat luas

\section{DAFTAR PUSTAKA}

Abdul Chaer dan Agustina. (2010). Sosiolinguistik Perkenalan Awal Jakarta: Rineka

Dardjowidjojo, Soenjono. (2003). Psikolinguistik: Pengantar Pemahaman Bahasa Manusia. Jakarta : Yayasan Obor Indonesia.

Ibrahim, Syukur. (1993). Kajian Tindak Tutur. Surabaya: Usaha Nasional.

Leech, Geofrey. (1993). Prinsip-prinsip Pragmatik. Jakarta: Universitas Indonesia.

Nadar, F. X. 2009. Pragmatik dan Penelitian Pragmatik.Yogyakarta: Graha Ilmu.

Rahardi, R. Kunjana. (2005). Pragmatik: Kesantunan Imperatif Bahasa Indonesia. Jakarta : Erlangga.

Searle, John R. (1969). Speech Act. London : Cambridge University Press.

Subroto, Edi. 1992. Metoda Penelitian Linguistik Struktural. Surakarta: Sebelas Maret University Press.

Sudaryat, Yayat. (2009). Makna dalam Wacana.Bandung: CV. Yrama Widya.
Sudaryanto. (1993). Metode dan Teknik Analisis Bahasa. Pengantar Penelitian

Wahana Kebudayaan secara Linguistis. Yogyakarta: Duta Wacana University Press.

Tarigan, Henry Guntur. 1986. Pengajaran Pragmatik. Bandung: Angkasa.

Wijana, Dewa Putu. (1996). Dasar-dasar Pragmatik. Yogyakarta: Andi Offset.

Wijana dan Rohmadi. (2009). Analisis Wacana Pragmatik. Surakarta: Yuma Pressindo.

(https://papuapost.wordpress.com/2017/01/2 2/teks-lengkap-pidato-inaugurasidonald-trump/) $\quad 11.36 \ldots 30 / 03 / 2017$

(http://www.rappler.com/indonesia/berita/15 9041-isi-pidato-pelantikan-donaldtrump-presiden-as) 11.22.....30/03/2017

https://www.artikata.com/arti-372364menyatakan.html 11/04/2017/11:06

https://www.merriamwebster.com/dictionary/will http://www.thefreedictionary.com/we bvb(https://notulabahasa.wordpress.com/201 3/12/16/kami-dan-kita-memangberbeda/. 
Telaga Bahasa, Vol. 5, No. 1, Juni 2017: 63-82 